\title{
Feeding by heterotrophic protists and copepods on the photosynthetic dinoflagellate Azadinium cf. poporum from western Korean waters
}

\author{
Éric Potvin ${ }^{1, *}$, Yeong Jong Hwang ${ }^{1}$, Yeong Du Yoo ${ }^{1}$, Jae Seong Kim ${ }^{2}$, Hae Jin Jeong ${ }^{1}$ \\ ${ }^{1}$ School of Earth and Environmental Sciences, College of Natural Sciences, Seoul National University, Seoul, 151-747, ROK \\ ${ }^{2}$ Saemankeum Environment Research Center, Kunsan National University, Kunsan, 573-701, ROK
}

\begin{abstract}
We explored the interactions between the photosynthetic dinoflagellate Azadinium cf. poporum isolated from Korean waters and potential predators, including engulfment feeders, a pallium feeder, peduncle feeders, and filter feeders. We measured the growth and/or ingestion rates of Oxyrrhis marina, Strobilidium sp., and Acartia spp. on A. cf. poporum as a function of prey concentrations. We also calculated grazing coefficients by using field data on abundance of Strobilidium sp.-sized naked ciliates co-occurring with $A$. cf. poporum and laboratory data on ingestion rates obtained in this study. Most of the tested organisms were able to feed on A. cf. poporum, but only O. marina, Strobilidium sp., and Acartia spp. showed sustained growth and/or ingestion on $A$. cf. poporum. Thus, some heterotrophic dinoflagellates using engulfment and filter feeders, such as ciliates and copepods, are likely to be optimal predators, while peduncle-feeding heterotrophic dinoflagellates are unlikely to efficiently feed due to the handling of the theca. The predators had low ratios of maximum growth rate to maximum ingestion rate on $A$. cf. poporum, as well as low gross growth efficiencies. Therefore, $A$. cf. poporum appears to be a low-quality prey for the predators tested. Grazing coefficients ranged between 0.052 and $0.446 \mathrm{~d}^{-1}$, suggesting that Strobilidium sp.-sized naked ciliates may sometimes have a high impact on A. cf. poporum populations, leading to the removal of up to $36 \%$ of the population in $1 \mathrm{~d}$. However, the low quality of the prey and predator selectivity in a more complex microbial community may reduce this impact.
\end{abstract}

KEY WORDS: Azadinium - Azaspiracids - Toxins - Seasonal dynamics · Grazing · Predation · Ingestion · Growth

- Resale or republication not permitted without written consent of the publisher

\section{INTRODUCTION}

The azaspiracids (AZAs) are the most recently discovered group of lipophilic marine biotoxins of microalgal origin associated with cases of shellfish poisoning in humans (Twiner et al. 2008). The production of AZAs was previously associated with a small photosynthetic dinoflagellate (Krock et al. 2009), designated as Azadinium spinosum Elbrächter et Tillmann and assigned to a new genus (Tillmann et al. 2009). The genus Azadinium is now composed of 4 well defined species, namely $A$. spinosum Elbrächter et Tillmann (Tillmann et al. 2009), A. obesum Tillmann et Elbrächter (Tillmann et al. 2010), A. poporum Tillmann et Elbrächter (Tillmann et al. 2011), and A. caudatum (Halldal) Nézan et Chomérat (Nézan et al. 2012). Undefined species were also described as $A$. cf. poporum (Potvin et al. 2012) and A. cf. spinosum (Akselman \& Negri 2012). Until recently, A. spinosum was the only known planktonic source of AZAs. However, new AZAs have since been discovered in $A$. poporum, A. cf. poporum, and the closely related species Amphidoma languida Tillmann, Salas et Elbrächter (Krock et al. 2012, Tillmann et al. 2012). A. 
obesum and A. caudatum are the only members of the genus Azadinium established in culture for which no AZA has been detected. While the AZAs produced by $A$. spinosum have been shown empirically to be toxic (Ito et al. 2002, Román et al. 2002, Colman et al. 2005, Twiner et al. 2005, Alfonso et al. 2006, Kulagina et al. 2006, Vale et al. 2007), research is pending for the new AZAs.

The population dynamics of the species of the genus Azadinium are not well known. These species apparently seem to either remain at low density, such as A. caudatum, which was not observed to exceed 1.3 cells ml ${ }^{-1}$ (Nézan et al. 2012), or are able to bloom (e.g. A. cf. spinosum) and can reach up to $9.03 \times 10^{3}$ cells ml ${ }^{-1}$ (Akselman \& Negri 2012).

Grazing pressure sometimes plays an important role in population dynamics (Watras et al. 1985). Heterotrophic dinoflagellates (HTDs), ciliates, and copepods are integral parts of marine planktonic food webs (Jeong et al. 2010). HTDs and ciliates can be found everywhere and can sometimes dominate in abundance and/or biomass, while copepods can similarly dominate the mesozooplankton (Brownlee \& Jacobs 1987, Lessard 1991, Jeong 1999, Turner et al. 2005). These 3 groups sometimes have considerable grazing impact on populations of diverse prey (Painting et al. 1993, Strom et al. 1993, Sherr \& Sherr 2007). In particular, grazing by heterotrophic protists is believed to contribute to the decline of blooms (Kim \& Jeong 2004). In order to investigate grazing pressure by predators, growth and ingestion need to be studied. No study extensively exploring predation on species of the genus Azadinium is currently available.

In order to determine which predators are more likely to grow and feed actively on Azadinium spp., we explored feeding of HTDs (Polykrikos kofoidii, Gyrodinium dominans, G. moestrupii, Oxyrrhis mar- ina, Oblea rotunda, Stoeckeria algicida, Pfiesteria piscicida, and Gyrodiniellum shiwhaense), a ciliate (Strobilidium sp.) and the copepods Acartia spp. on Azadinium cf. poporum. We found that O. marina, Strobilidium sp., and Acartia spp. fed well on $A$. cf. poporum. Therefore, we measured their growth and/ or ingestion rates on $A$. cf. poporum as a function of prey concentration. Furthermore, we calculated grazing coefficients by using field data on abundance of Strobilidium sp.-sized naked ciliates co-occurring with $A$. cf. poporum and laboratory data on ingestion rate obtained in this study. Our results provide a basis for understanding interactions between Azadinium spp. and common heterotrophic protists and copepods.

\section{MATERIALS AND METHODS}

\section{Preparation of experimental organisms}

For the isolation and culture of Azadinium cf. poporum (GenBank accession number = FR877580), surface sediment samples from Shiwha Bay, a highly eutrophic bay in Korea $\left(37^{\circ} 18^{\prime} \mathrm{N}, 126^{\circ} 36^{\prime} \mathrm{E}\right)$, were incubated in F/2-Si medium (Guillard \& Ryther 1962) in a growth chamber at $20^{\circ} \mathrm{C}$ under an illumination of $20 \mu \mathrm{E} \mathrm{m} \mathrm{m}^{-2} \mathrm{~s}^{-1}$ of cool white fluorescent light on a 14:10 h light:dark cycle. The monoclonal culture was established as described in detail by Potvin et al. (2012).

For the isolation and culture of potential protistan predators, plankton samples collected with water samplers were taken from the Korean coastal waters off Shiwha, Masan, Saemankeum, Karorim and Jinhae between 2007 and 2011 (Table 1). A clonal culture of each predator was established as in Kim \& Jeong (2004), Jeong et al. (2003a,b, 2005a, 2006,

Table 1. Isolation and maintenance conditions of the experimental organisms. Sampling location in Korea and time, field water temperature $\left(\mathrm{T},{ }^{\circ} \mathrm{C}\right)$, and salinity $(\mathrm{S})$ from which species were isolated, and prey species and concentrations $\left(\mathrm{cells}^{-1}\right)$ for maintenance. All organisms are heterotrophic dinoflagellates, except Strobilidium sp., a ciliate

\begin{tabular}{|lccccccc}
\hline Organism & Location & Year (month) & T & S & Prey species & Concentration \\
\hline Gyrodiniellum shiwhaense & Shiwha Bay & $2009(09)$ & 24.5 & 24.0 & Amphidinium carterea & 20000 \\
Gyrodinium dominans & Masan Bay & $2007(04)$ & 15.1 & 33.4 & Amphidinium carterea & 8000 \\
Gyrodinium moestrupii & Saemankeum Bay & $2009(10)$ & 21.2 & 31.0 & Alexandrium minutum & $3000-5000$ \\
Oblea rotunda & Shiwha Bay & $2010(08)$ & 26.8 & 23.7 & Prorocentrum minimum & 30000 \\
Oxyrrhis marina & Karorim & $2010(05)$ & 19.5 & 33.0 & Amphidinium carterea & 8000 \\
Pfiesteria piscicida & Jinhae & $2010(02)$ & 24.5 & 12.6 & Amphidinium carterea & $20000-30000$ \\
Polykrikos kofoidii & Shiwha Bay & $2010(03)$ & 9.2 & 23.4 & Scrippsiella trochoidea & 8000 \\
Stoeckeria algicida & Masan Bay & $2007(08)$ & 24.5 & 29.7 & Heterosigma akashiwo & 30000 \\
Strobilidium sp. & Shiwha Bay & $2011(08)$ & 27.0 & 15.0 & Heterocapsa rotundata & $50000-60000$ \\
\hline
\end{tabular}


2011b), Kang et al. (2011), and Yoon et al. (2012). Oblea rotunda was brought into culture as Gyrodinium spp. in Kim \& Jeong (2004; Table 1). The cultures were maintained on a wheel rotating at $0.9 \mathrm{rpm}$ in a growth chamber at $20^{\circ} \mathrm{C}$ under an illumination of $20 \mu \mathrm{E} \mathrm{m} \mathrm{m}^{-2} \mathrm{~s}^{-1}$ of cool white fluorescent light on a 14:10 h light:dark cycle. Fresh prey cells were provided every 1 to $3 \mathrm{~d}$.

The copepods Acartia spp. were collected from Kunsan port with a $303 \mu \mathrm{m}$ mesh net in May 2011 when water temperature and salinity were $16.8^{\circ} \mathrm{C}$ and 18.9, respectively. The copepods were acclimated in a room at $20^{\circ} \mathrm{C}$, with Prorocentrum minimum provided as prey. Species of the genus Acartia, which co-occur in coastal waters off western Korea, can be very similar and impossible to distinguish from each other when they are alive (e.g. Soh \& Suh 2000). Therefore, we had to use a mixture of adult Acartia spp.

The mean equivalent spherical diameter (ESD) of live Azadinium cf. poporum was measured (ESD = $10.0 \mu \mathrm{m})$ by an electronic particle counter and size analyzer (model Z2, Beckman Coulter). The shape of a sphere was used to estimate the volume of $A$. cf. poporum based on the ESD. Oxyrrhis marina and Strobilidium sp. were measured in order to estimate their volume in the different predator-prey combinations at the end of the incubation. Measurements were made with specimens fixed in 5\% acid Lugol's solution using a transmitted light inverted microscope (Zeiss Axiovert 200M, Carl Zeiss) at a magnification of $400 \times$ with a Zeiss AxioCam MRc5 digital camera (Carl Zeiss). The shape of O. marina was estimated as 2 cones joined at their bases. The shape of Strobilidium sp. was estimated as a sphere, cylinder, or cone depending of the shape of the specimen. Carbon content was estimated from the cell volume according to Menden-Deuer \& Lessard (2000).

\section{Feeding}

Expt 1 was designed to test whether Polykrikos kofoidii, Gyrodinium dominans, G. moestrupii, Oxyrrhis marina, Oblea rotunda, Stoeckeria algicida, Pfiesteria piscicida, Gyrodiniellum shiwhaense, Strobilidium sp., and Acartia spp. were able to feed on Azadinium cf. poporum (Table 2).

Azadinium cf. poporum (10 000 cells ml ${ }^{-1}$ final concentration) was added to $80 \mathrm{ml}$ polycarbonate (PC) bottles, followed by the addition of each of the other HTDs (100 to 3000 cells ml ${ }^{-1}$ final concentration), the ciliates (20 cells ml ${ }^{-1}$ final concentration), or the copepods (0.025 ind. $\mathrm{ml}^{-1}$ final concentration). Duplicates were established for each predator put into contact with A. cf. poporum. One control bottle (without prey) was set up for each experiment. The bottles were placed on a plankton wheel rotating at $0.9 \mathrm{rpm}$ in a growth chamber at $20^{\circ} \mathrm{C}$ under an illumination of $20 \mu \mathrm{E} \mathrm{m}{ }^{-2} \mathrm{~s}^{-1}$ of cool white fluorescent light on a 14:10 h light:dark cycle.

Aliquots $(5 \mathrm{ml})$ were removed from each bottle after $1,2,6$, and $24 \mathrm{~h}$ of incubation and then transferred into 6-well plate chambers or onto microscopic

Table 2. Experimental design to assess predation by various planktonic predator species on the prey species Azadinium cf. poporum. The numbers in prey and predator columns are the actual initial concentrations (cells or ind. $\mathrm{ml}^{-1}$ ) of prey and predator. In each experiment, the lowest $A$. cf. poporum concentration was tested against the lowest predator concentration, the next lowest against the next lowest, etc. Values within parentheses in the prey and predator columns are the corresponding prey and predator concentrations in the predator-only control bottles. Feeding occurrence of each predator on A. cf. poporum in Expt 1 is represented by $\mathrm{Y}$ (feeding observed) or $\mathrm{N}$ (no feeding observed)

\begin{tabular}{|c|c|c|c|c|}
\hline Expt & Prey concentration & Species & Predator concentration & Feeding \\
\hline \multirow[t]{10}{*}{1} & 10000 & Gyrodiniellum shiwhaense & 1000 & $\mathrm{Y}$ \\
\hline & & Gyrodinium dominans & 500 & $\mathrm{Y}$ \\
\hline & & Gyrodinium moestrupii & 500 & $\mathrm{Y}$ \\
\hline & & Oblea rotunda & 500 & $\mathrm{~N}$ \\
\hline & & Oxyrrhis marina & 3000 & $\mathrm{Y}$ \\
\hline & & Pfiesteria piscicida & 3000 & $\mathrm{Y}$ \\
\hline & & Polykrikos kofoidii & 100 & $\mathrm{~N}$ \\
\hline & & Stoeckeria algicida & 1000 & $\mathrm{~N}$ \\
\hline & & Strobilidium sp. & 20 & $\mathrm{Y}$ \\
\hline & & Acartia spp. & 0.025 & $\mathrm{Y}$ \\
\hline 2 & $44,282,1223,2991,9600,22758(0)$ & Oxyrrhis marina & $5,12,24,36,53,106(7,261)$ & \\
\hline 3 & $62,558,2415,5536,11771,22919,59267(0)$ & Strobilidium sp. & $6,6,6,15,13,13,29(7,28)$ & \\
\hline 4 & $52,151,492,1895,6553,27070,52332(0)$ & Acartia spp. & $.02,0.02,0.02,0.02,0.02,0.02,0.02$ & $0.02)$ \\
\hline
\end{tabular}


slides. Approximately 200 cells of each predator were observed using a transmitted light inverted microscope (Zeiss Axiovert 200M, Carl Zeiss) at a magnification of $100 \times$ to $630 \times$ to determine whether the predators were able to feed on Azadinium cf. poporum. Cells of predators containing ingested $A$. cf. poporum cells were photographed using a Zeiss AxioCam MRc5 digital camera at a magnification of $630 \times$. To confirm the absence of prey ingestion, higher prey concentrations were provided.

\section{Growth, ingestion, and gross growth efficiency}

Expts 2 and 3 were designed to measure the growth and ingestion rates of Oxyrrhis marina and Strobilidium sp. as a function of the prey concentration when fed on Azadinium cf. poporum (Table 2). Only this HTD and this ciliate were shown to feed and to have sustained growth on $A$. cf. poporum among the protists tested.

Two weeks before the experiments were conducted, dense cultures of Oxyrrhis marina and Strobilidium sp. growing on algal prey listed in Table 1 were transferred into $500 \mathrm{ml}$ PC bottles containing Azadinium cf. poporum (ca. 20000 cells ml ${ }^{-1}$ final concentration). These predator cultures were transferred to $500 \mathrm{ml} \mathrm{PC}$ bottles of fresh prey (ca. 20000 cells $\mathrm{ml}^{-1}$ final concentration) every 1 to $3 \mathrm{~d}$. The bottles were filled to capacity with freshly filtered seawater, capped, and placed on plankton wheels rotating at $0.9 \mathrm{rpm}$ and incubated under the conditions described above. To monitor the conditions and interactions between the predator and prey species, the cultures were periodically removed from the rotating wheels, examined through the surface of the capped bottles by using a stereomicroscope (Olympus, SZX12), and then returned to the rotating wheels. Once the target prey cells in ambient water were no longer detectable, predators were routinely inspected until the prey cells were no longer observed in the cytoplasm. This was carried out to minimize possible residual growth resulting from the ingestion of prey during batch culture. Once the predators were starved, the cultures were then used to conduct the experiments.

For each experiment, the initial concentrations of protists were established using an autopipette to deliver predetermined volumes of known cell concentrations to the bottles. Triplicate $42 \mathrm{ml}$ (for the HTD) or $80 \mathrm{ml}$ (for the ciliate) experimental bottles (mixtures of predator and prey) and triplicate control bottles (prey only) were set up for each predator-prey combination. Triplicate control bottles containing only predators were also established at 2 predator concentrations. F/2-Si medium $(5 \mathrm{ml}$ for the HTD, $10 \mathrm{ml}$ for the ciliate) was added to all PC bottles. To obtain similar water conditions, the water of the predator culture was filtered through a $0.7 \mu \mathrm{m}$ GF/F filter and then added to the prey control bottles in the same amount as the volume of the predator culture added to the experiment bottles for each predator-prey combination. Culture of Azadinium cf. poporum was filtered and added to the predator control bottles in the same way as for the prey control bottles. All bottles were then filled to capacity with filtered seawater and capped. To determine the actual protist concentrations at the beginning of the experiment, a 5 or $6 \mathrm{ml}$ aliquot was taken from each bottle for the HTD and ciliate, respectively. The bottles were refilled to capacity with freshly filtered seawater, capped, and placed on rotating wheels under the conditions described above. Dilution of the cultures associated with refilling was considered when calculating growth and ingestion rates. Another aliquot of the same volume as before was taken from each bottle after 48 or $24 \mathrm{~h}$ for the HTD and ciliate, respectively. The aliquots were fixed with $5 \%$ acid Lugol's solution (final concentration). The abundances of predator and prey were determined by counting all or $>300$ cells in 3 Sedgwick-Rafter chambers (SRCs, $1 \mathrm{ml}$ ). The conditions of the predator and its prey were assessed using a stereomicroscope as described above before subsampling.

Expt 4 was designed to measure only the ingestion and clearance rates of Acartia spp. on Azadinium cf. poporum as a function of the prey concentration (Table 2). Adult female Acartia spp. were used.

The initial concentration of Acartia spp. was determined by the individual transfer of the copepods using a Pasteur pipette with a stereomicroscope (Olympus, SZX-12). Triplicate $500 \mathrm{ml}$ experimental bottles (mixtures of predator and prey) and triplicate control bottles (prey only) were set up for each predator-prey combination. Triplicate control bottles containing only predators were also established at 1 predator concentration. F/2-Si medium (50 ml) was added to all PC bottles. To obtain similar water conditions, the same procedures described above were followed. Furthermore, the actual protist concentrations at the beginning and end of the experiment were determined as before by taking a $10 \mathrm{ml}$ aliquot. The final concentration of Acartia spp. was determined by direct counting with a stereomicroscope (Olympus, SZX-12). 
The specific growth rate of predators, $\mu\left(\mathrm{d}^{-1}\right)$, was calculated as:

$$
\mu=\left[\operatorname{Ln}\left(P_{t} / P_{0}\right)\right] / t
$$

where $P_{0}$ and $P_{t}$ are the concentrations of predators at 0 and $48 \mathrm{~h}$ for the HTD, and at 0 and $24 \mathrm{~h}$ for the ciliate, and $t$ is the time elapsed during the experiment.

Growth rates were fit to the Michaelis-Menten model (Michaelis \& Menten 1913). The equation for growth rate data is:

$$
\mu=\mu_{\max }\left(X-X^{\prime}\right) /\left[K_{\mathrm{GR}}+\left(X-X^{\prime}\right)\right]
$$

where $\mu_{\max }$ is the maximum growth rate $\left(\mathrm{d}^{-1}\right) ; X$ is the prey concentration (cells ml ${ }^{-1}$ or $\mathrm{ng} \mathrm{C} \mathrm{ml}^{-1}$ ), $X^{\prime}$ is the threshold prey concentration (the prey concentration where $\mu=0), K_{\mathrm{GR}}$ is the prey concentration sustaining half of $\mu_{\max }$. Data were iteratively fitted to this regression type using DeltaGraph ${ }^{\circledR}$ (Delta Point) and the Levenberg-Marquardt algorithm, which minimizes the sum of squares of differences between the dependent variables in the equation and the observed data.

Ingestion and clearance rates were calculated using the equations of Frost (1972) and Heinbokel (1978). The incubation times for calculating ingestion and clearance rates were the same as those for estimating growth rates. The data on the ingestion rates were fit to the Michaelis-Menten model or a simple linear regression model depending of the functional response. The Michaelis-Menten equation for ingestion rate (IR) data is:

$$
\mathrm{IR}=I_{\max }(X) /\left[K_{\mathrm{IR}}+(X)\right]
$$

and the simple linear regression equation is:

$$
\operatorname{IR}=\mathrm{C}_{1}(X)+\mathrm{C}_{2}
$$

where $I_{\max }$ is the maximum ingestion rate (cells predator ${ }^{-1} \mathrm{~d}^{-1}$ or ng $\mathrm{C}$ predator $\left.{ }^{-1} \mathrm{~d}^{-1}\right) ; X$ is the prey concentration (cells ml ${ }^{-1}$ or $\mathrm{ng} \mathrm{C} \mathrm{ml}^{-1}$ ), $K_{\mathrm{IR}}$ is the half saturation constant (the prey concentration sustaining half of $I_{\max }$ ), and $\mathrm{C}_{1}$ and $\mathrm{C}_{2}$ are constants.

Gross growth efficiency (GGE), defined as predator biomass produced (+) or lost (-) per prey biomass ingested, was calculated from estimates of carbon content per cell based on cell volume for each mean prey concentration.

\section{Field data}

Water samples were obtained at least at monthly intervals in ice-free conditions from January 2009 to December 2011 in Shiwha Bay, Korea, at different stations from the surface and $1 \mathrm{~m}$ above the bottom (Fig. 1). To quantify cells based on optical microscopy, samples were fixed with $5 \%$ acid Lugol's solution (final concentration) and used to determine the abundance of Oxyrrhis marina and Strobilidium sp.sized naked ciliates. Azadinium cf. poporum cannot be differentiated easily from species of its own genus and other species highly similar morphologically based on optical microscopy. Therefore, real-time PCR was used to estimate its concentration in the field. Field samples were concentrated by the filtration of $100 \mathrm{ml}$ of seawater with a $25 \mathrm{~mm}$ GF/C glass microfiber filter (Whatman ${ }^{\mathrm{TM}}$ ) and immediately frozen on dry ice. Filters were subsequently stored at $-20^{\circ} \mathrm{C}$ until further processing.

Fixed field samples were settled for $48 \mathrm{~h}$. They were then concentrated by gently removing the surface water. To determine the concentration of Oxyrrhis marina and Strobilidium sp.-sized naked ciliates, an aliquot was removed from each concentrated field sample and examined with a compound microscope

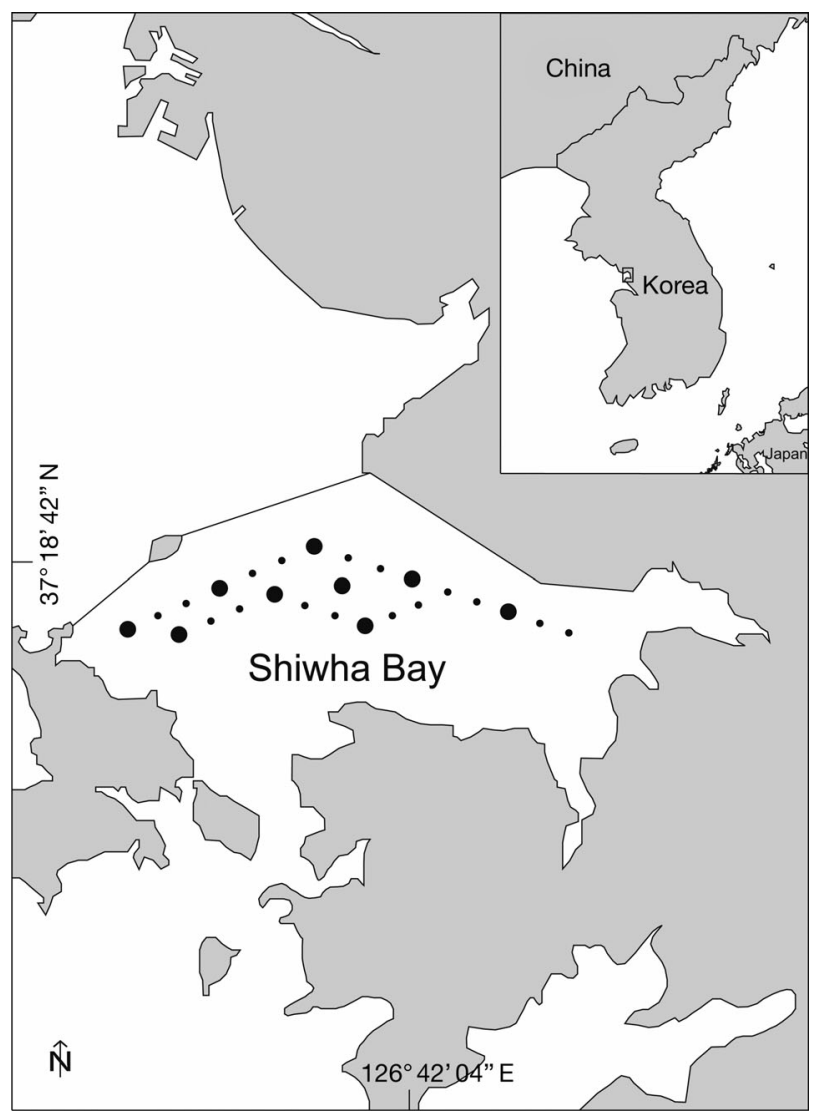

Fig. 1. Shiwha Bay, Korea, and fixed stations where water samples were collected. Surface water samples used for protistan determination and real-time PCR were taken at every station, while bottom water samples were only taken at stations represented by enlarged circles 
to determine their abundances by enumerating the cells in three $1 \mathrm{ml}$ SRCs. The protists were enumerated at $40 \times$ to $200 \times$ magnification.

After the filters stored at $-20^{\circ} \mathrm{C}$ had defrosted, cells were resuspended by adding TE buffer (Tris $\mathrm{HCl} \mathrm{pH} 8.010 \mathrm{mM}$, EDTA $1 \mathrm{mM}$, Bioneer) and grinding the filters in $2 \mathrm{ml}$ tubes (GenePole). The suspension was subsequently boiled at $100^{\circ} \mathrm{C}$ for $5 \mathrm{~min}$ and cooled at room temperature for $20 \mathrm{~min}$. We added $850 \mu$ l of 25:24:1 phenol:chloroform: isoamyl alcohol (Bioneer) and mixed by vortexing. The samples were subsequently centrifuged (Hanil Science, model MICRO 17TR) at $17640 \times g$ (30 min at $20^{\circ} \mathrm{C}$ ). The supernatant was transferred to a DNA binding column (Bioneer) and subsequently centrifuged at $2250 \times g\left(1 \mathrm{~min}\right.$ at $\left.20^{\circ} \mathrm{C}\right)$. We then added $700 \mu \mathrm{l}$ of $99.5 \%$ ethanol (Merck) at $-20^{\circ} \mathrm{C}$ and $30 \mu \mathrm{l}$ $3 \mathrm{M}$ sodium acetate $(\mathrm{pH} 7.0$, Bioneer) to the binding column. The mixture was subsequently incubated at $-20^{\circ} \mathrm{C}$ for $1 \mathrm{~h}$. The mixture was then centrifuged at $2250 \times g\left(1 \mathrm{~min}\right.$ at $\left.4^{\circ} \mathrm{C}\right)$. The pellet was then washed twice by the addition of $70 \%$ ethanol (Merck) followed by centrifugation at $2250 \times g\left(1 \mathrm{~min}\right.$ at $\left.4^{\circ} \mathrm{C}\right)$. The pellet contained in the binding column was subsequently dried at $50^{\circ} \mathrm{C}$ for $1 \mathrm{~h}$. TE buffer $(200 \mu \mathrm{l})$ was added to the binding column. The binding column was left to stand for more than $10 \mathrm{~min}$ in order to resuspend the DNA. Finally, the binding column was centrifuged at 1440 $\times g(5 \mathrm{~min})$ followed by $17640 \times g$ (5 min). The crude extracts and 1:10 dilutions were stored at $-20^{\circ} \mathrm{C}$ until further use in real-time PCR assays. A preliminary survey was done with the undiluted and diluted extracts for each sample collected. Each positive assay of this survey was measured in triplicate.

The design of the primers and the probe was based on the ITS rDNA region sequences of all species of the genus Azadinium available from GenBank. Sequences were aligned using the program Clustal X2 (Larkin et al. 2007). Manual searches of the alignment were conducted to determine unique sequences and to develop an A. cf. poporum specific real-time PCR assay. The primers and probe sequences as well as their general properties were determined with Primer 3 (Rozen \&
Skaletsky 2000). Their secondary structures were analyzed with OligoCalc (Kibbe 2007). Subsequently, the primers and probe were synthesized by Biosearch Technologies (Novato, CA). The probe was dual-labeled with the fluorescent dye FAM and the BHQ-1 quencher at the $5^{\prime}$ and $3^{\prime}$ ends, respectively. The sequences of the primers and probe were checked against published sequences in GenBank by BLAST homology search. BLAST searches showed that the sequences of the selected primers and probe matched only with the sequences of $A$. cf. poporum. The specificity was further assessed with the DNA from 22 dinoflagellate cultures (Table 3) extracted as in Potvin et al. (2012). Agarose gel analysis of the PCR products showed only amplicons of the expected size (94 bp) for A. cf. poporum and no product for other species. Real-time PCR experiments showed that the primers-probe set was specific to the target for which it was designed.

To achieve optimal performance, series of primers and probe concentrations as well as annealingextension times and temperatures were tested by real-time PCR assays. The tested primers and probe concentrations ranged from 200 to 1000 and 100 to $500 \mathrm{nM}$, respectively. The tested annealing-ex-

Table 3. Isolation conditions of the dinoflagellates used in the real-time PCR specificity test. Sampling location and time, field water temperature $\left(\mathrm{T},{ }^{\circ} \mathrm{C}\right)$, and salinity (S) are shown. na: not available

\begin{tabular}{|lcccc|}
\hline Dinoflagellate & Location & Year (month) & T & S \\
\hline Azadinium cf. poporum & Shiwha Bay, Korea & $2010(06)$ & $24.1^{\text {a }}$ & $26.7^{\mathrm{a}}$ \\
Bysmatrum caponii & Karorim, Korea & $2010(05)$ & 19.5 & 33.0 \\
Cryptoperidiniopsis brodyi & Pamlico River, USA & $1992(07)$ & na & na \\
Dinophysis acuminata & Masan Bay, Korea & $2005(12)$ & na & na \\
Gymnodinium aureolum & Kunsan, Korea & $2008(03)$ & 10.0 & 30.5 \\
Gymnodinium simplex & Shiwha Bay, Korea & $2009(09)$ & 25.1 & 24.0 \\
Gyrodiniellum shiwhaense & Shiwha Bay, Korea & $2009(09)$ & 24.5 & 24.0 \\
Gyrodinium moestrupii & Saemangum Bay, Korea & $2009(10)$ & 21.2 & 31.0 \\
Heterocapsa rotundata & Kunsan, Korea & $2002(05)$ & 16.6 & 22.0 \\
Heterocapsa triquetra & Masan Bay, Korea & $2008(06)$ & 20.2 & 29.0 \\
Karenia brevis & Gulf of Mexico, USA & $1999(09)$ & na & na \\
Karlodinium veneficum & Shiwha Bay, Korea & $2011(08)$ & 27.1 & 7.2 \\
Oxyrris marina & Karorim, Korea & $2010(05)$ & 19.5 & 33.0 \\
Paragymnodinium & Shiwha Bay, Korea & $2006(05)$ & 18.8 & 30.4 \\
shiwhaense & & & & \\
Pfiesteria piscicida & Jinhae, Korea & $2010(02)$ & 24.5 & 12.6 \\
Prorocentrum donghaiense & Jeju, Korea & $2010(06)$ & na & na \\
Prorocentrum micans & Shiwha Bay, Korea & $2009(10)$ & 16.8 & 27.0 \\
Prorocentrum minimum & Shiwha Bay, Korea & $2009(01)$ & 1.2 & 30.3 \\
Scrippsiella precaria & Shiwha Bay, Korea & $2009(06)$ & 22.8 & 27.6 \\
Scrippsiella sweeneyae & Masan Bay, Korea & $2009(08)$ & 27.0 & 31.5 \\
Stoeckeria algicida & Masan Bay, Korea & $2007(08)$ & 24.5 & 29.7 \\
Woloszynskia cincta & Shiwha Bay, Korea & $2009(06)$ & 22.0 & 29.3 \\
asolated from sediment & & & & \\
\hline & & & & \\
\hline
\end{tabular}


tension times and temperatures ranged from 45 to $85 \mathrm{~s}$ and 56 to $64^{\circ} \mathrm{C}$, respectively. The conditions that provided the lowest cycle threshold (CT) value and the highest fluorescence were selected. PCR assays were performed on a Rotor-Gene 6000 (Corbett Research). The following reagents were added in the reaction mixture: $5 \mu \mathrm{l}$ of $2 \times$ SensiMix II Probe (GenePole), forward (5'-GGG AAC CTT CGC ATC AAT CAA C -3') and reverse (5'-CAC GAA GCA GCC TTG GGT TT-3') primers each at a final concentration of $0.2 \mu \mathrm{M}$, probe (5'-TGA GTG TCT TTG ATA CCA TCT GTT GCA-3') at a final concentration of $0.15 \mu \mathrm{M}, 1 \mu \mathrm{l}$ of template DNA, and nucleasefree water (GenePole) to a final volume of $10 \mu \mathrm{l}$. The thermal cycling conditions consisted of $10 \mathrm{~min}$ at $95^{\circ} \mathrm{C}$ followed by 50 cycles of $10 \mathrm{~s}$ at $95^{\circ} \mathrm{C}$ and $65 \mathrm{~s}$ at $60^{\circ} \mathrm{C}$. Fluorescence data were collected at the end of each cycle, and determination of the cycle threshold line was carried out automatically by the instrument. PCR products that were positive were further analyzed by gel electrophoresis to confirm the amplicon size. Three samples that gave positive real-time PCR results were reamplified without the probe. The PCR products were purified using the AccuPrep ${ }^{\circledR}$ PCR purification kit (Bioneer) according to the manufacturer's instructions. The purified DNA was sent to the Genome Research Facility (School of Biological Science, Seoul National University, Korea) and sequenced with a ABI PRISM ${ }^{\circledR}$ 3700 DNA Analyzer (Applied Biosystems). All sequences obtained corresponded to Azadinium cf. poporum.

A standard curve using cell numbers was constructed from Azadinium cf. poporum culture. Cell numbers (100000 cells) were estimated by counting 3 SRCs, and genomic DNA was extracted the same way as for the field samples. Ten-fold serial dilutions of the DNA extract were used to construct the standard curve. A strong linear relationship between the CT values and the log of the cell numbers was established, with a correlation coefficient $\left(\mathrm{r}^{2}\right)$ of 0.999 . The cell number of $A$. cf. poporum in field samples was determined from $\mathrm{CT}$ values and comparison with the standard curve.

\section{Grazing impact}

We calculated grazing coefficients by using field data on the abundance of Strobilidium sp.-sized naked ciliates (25 to $60 \mu \mathrm{m}$ in length) co-occurring with Azadinium cf. poporum and laboratory data on ingestion rate. We assumed that the ingestion rates of
Strobilidium sp.-sized naked ciliates on A. cf. poporum were the same as those obtained in this study.

The grazing coefficients $\left(g, \mathrm{~d}^{-1}\right)$ were calculated as:

$$
g=\mathrm{CR} \times \mathrm{GC} \times 24
$$

where CR is the clearance rate $\left(\mathrm{ml}\right.$ predator $\left.^{-1} \mathrm{~h}^{-1}\right)$ of a predator on Azadinium cf. poporum at a given prey concentration, and GC is the grazer concentration (cells ml $\mathrm{m}^{-1}$ ). CRs were calculated as:

$$
\mathrm{CR}=\mathrm{IR} / X
$$

where IR is the ingestion rate (cells eaten predator $^{-1}$ $\mathrm{h}^{-1}$ ) of the predator on the prey and $X$ is the prey concentration (cells ml ${ }^{-1}$ ). CRs were corrected using $Q_{10}$ $=2.8$ (Hansen et al. 1997) because in situ water temperatures and the temperature used in the laboratory for the experiments $\left(20^{\circ} \mathrm{C}\right)$ were sometimes different.

\section{Swimming speed}

A culture of Azadinium cf. poporum (ca. 20000 cells ml $\mathrm{m}^{-1}$ ) growing at $20^{\circ} \mathrm{C}$ under an illumination of $20 \mu \mathrm{E} \mathrm{m} \mathrm{m}^{-2} \mathrm{~s}^{-1}$ of cool white fluorescent light on a 14:10 h light:dark cycle in F/2-Si medium was added to a $50 \mathrm{ml}$ cell culture flask and allowed to acclimate for $30 \mathrm{~min}$. The video camera focused on 1 field seen as 1 circle in a cell culture flask under a stereomicroscope (Olympus, SZX-12) at $20^{\circ} \mathrm{C}$, and swimming of $A$. cf. poporum cells was then recorded at a magnification of $40 \times$ using a video analyzing system (Samsung, SV-C660) and a CCD camera (Hitachi, KP-D20BU). The swimming speed was calculated based on the linear displacement of cells in 1 s. The average swimming speed was calculated based on the measures of 30 cells during singleframe playback. The swimming of individual cells was interrupted by short and high-speed 'jumps' in various directions typical of the genus Azadinium (Tillmann et al. 2009). These 'jumps' were excluded from the measurements.

\section{RESULTS}

Among the predators tested, Gyrodinium dominans, G. moestrupii, Oxyrrhis marina, Pfiesteria piscicida, Gyrodiniellum shiwhaense, Strobilidium sp., and Acartia spp. were able to feed on Azadinium cf. poporum (Fig. 2), while Polykrikos kofoidii, Oblea rotunda, and Stoeckeria algicida were not. Only the HTD $O$. marina and the ciliate Strobilidium sp. showed sustained growth on A. cf. poporum. 

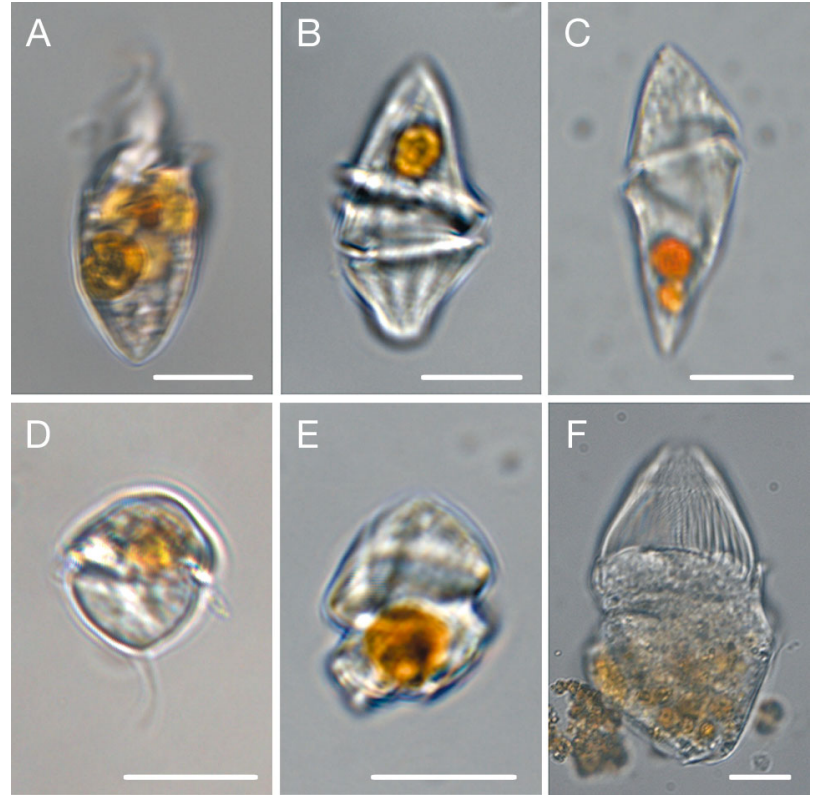

Fig. 2. Feeding by (A-E) heterotrophic dinoflagellates and (F) a ciliate on Azadinium cf. poporum. (A) Oxyrrhis marina with several ingested A. cf. poporum cells, (B) Gyrodinium dominans with an ingested A. cf. poporum cell, (C) Gyrodinium moestrupii with 2 ingested $A$. cf. poporum cells, (D) Pfiesteria piscicida with an ingested $A$. cf. poporum cell, (E) Gyrodiniellum shiwhaense with an ingested $A$. cf. poporum cell, (F) Strobilidium sp. with several ingested A. cf. poporum cells. All photographs were taken by means of an inverted microscope using Zeiss AxioCam MRc5 digital camera at a magnification of $630 \times$. Scale bars $=10 \mu \mathrm{m}$

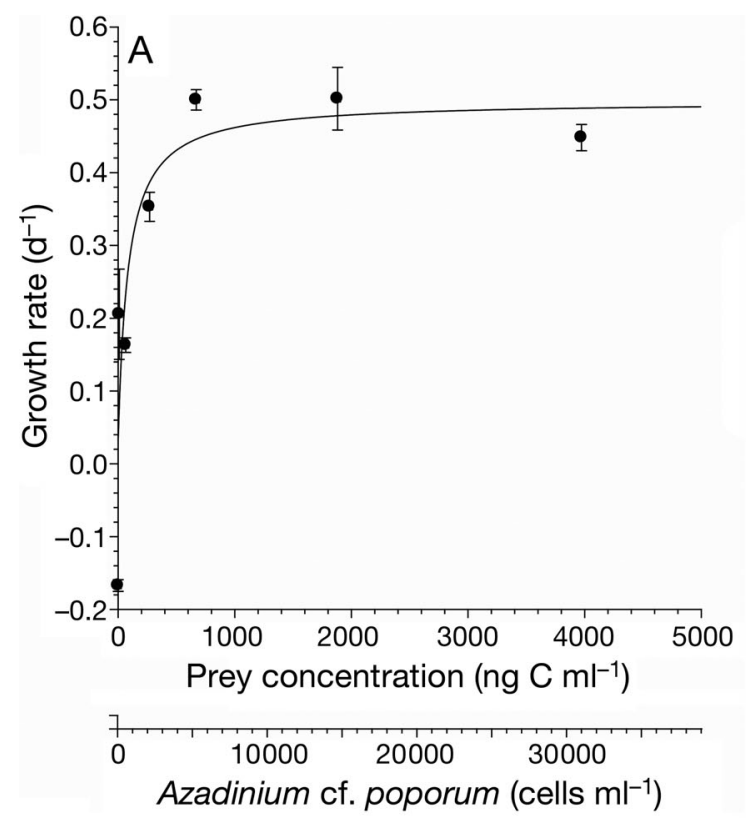

\section{Growth rate}

The growth rate of Oxyrrhis marina on Azadinium cf. poporum rapidly increased up to ca. $5.2 \times 10^{3}$ cells $\mathrm{ml}^{-1}$ (669 $\mathrm{ng} \mathrm{C} \mathrm{ml}^{-1}$ ), but became saturated at the higher prey concentrations (Fig. 3A). When the data were fitted to Eq. (2), the maximum growth rate $\left(\mu_{\max }\right)$ of $O$. marina on A. cf. poporum was $0.497 \mathrm{~d}^{-1}$ and the threshold prey concentration for the growth of the predator was 4 cells ml-1 $\left(0.509 \mathrm{ng} \mathrm{C} \mathrm{ml}^{-1}\right)$. The prey concentration sustaining half of $\mu_{\max }$ was 619 cells ml ${ }^{-1}$ (79.4 $\mathrm{ng} \mathrm{C} \mathrm{ml}^{-1}$ ).

The growth rate of Strobilidium sp. on Azadinium cf. poporum rapidly increased up to ca. $4.6 \times 10^{3}$ cells $\mathrm{ml}^{-1}$ (590 ng C ml${ }^{-1}$ ), but became saturated at the higher prey concentrations (Fig. 3B). When the data were fitted to Eq. (2), the $\mu_{\max }$ of Strobilidium sp. on A. cf. poporum was $0.636 \mathrm{~d}^{-1}$ and the threshold prey concentration for the growth of the predator was 1.4 $\times 10^{3}$ cells ml ${ }^{-1}\left(185 \mathrm{ng} \mathrm{C} \mathrm{ml}^{-1}\right)$. The prey concentration sustaining half of $\mu_{\max }$ was $2.1 \times 10^{3}$ cells ml $^{-1}$ (268 $\mathrm{ng} \mathrm{C} \mathrm{ml}^{-1}$ ).

\section{Ingestion rate}

The ingestion rate of Oxyrrhis marina on Azadinium cf. poporum increased rapidly with mean prey concentration up to ca. $5.2 \times 10^{3}$ cells ml $^{-1}(669 \mathrm{ng}$

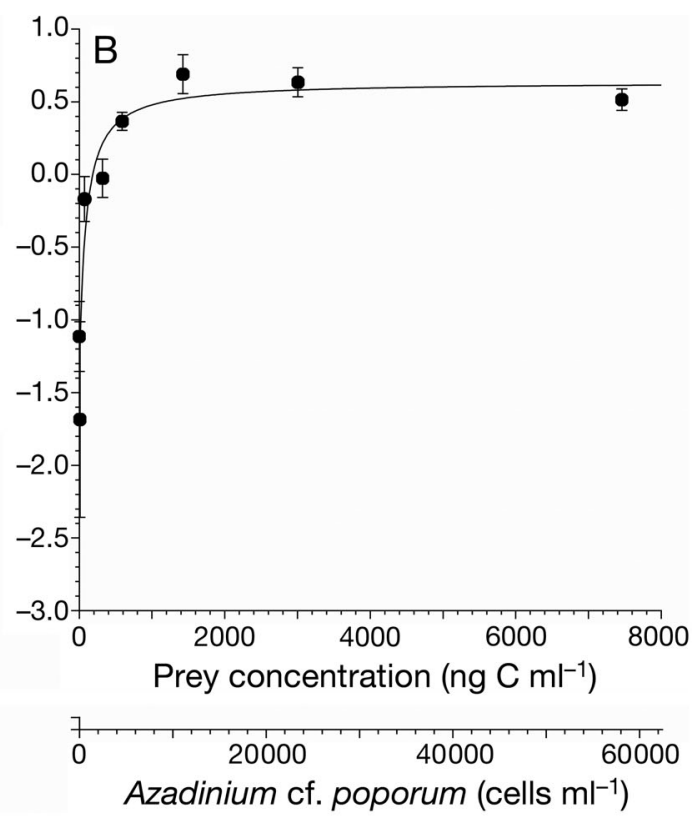

Fig. 3. Oxyrrhis marina and Strobilidium sp. Specific growth rate $\left(\mu, \mathrm{d}^{-1}\right)$ of $(\mathrm{A})$ the heterotrophic dinoflagellate and (B) a ciliate feeding on the dinoflagellate Azadinium cf. poporum as a function of mean prey concentration $(X)$. Symbols represent treatment means \pm 1 SE. A Michaelis-Menten equation (Eq. 2) was used to produce curves for (A) and (B) for all treatments in the experiments. (A) $\mu=0.497(X-0.509) /[79.4+(X-0.509)], \mathrm{r}^{2}=0.776$; (B) $\mu=0.636(X-185) /[268+(X-185)], \mathrm{r}^{2}=0.744$ 

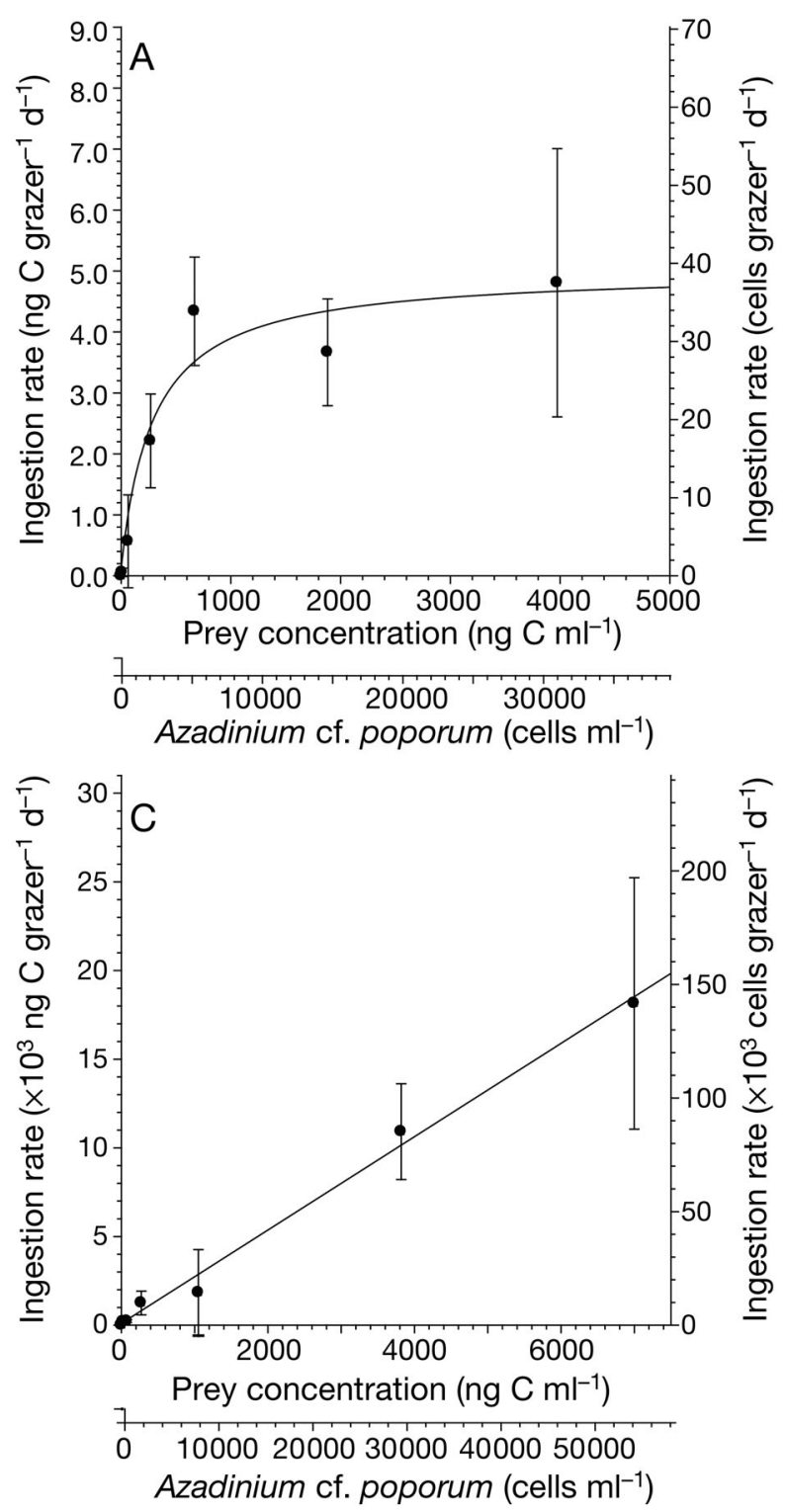

$\mathrm{C} \mathrm{ml}^{-1}$ ), but became saturated at higher concentrations (Fig. 4A). When the data were fitted to Eq. (3), the maximum ingestion rate $\left(I_{\max }\right)$ of $O$. marina on $A$. cf. poporum was 39 cells predator ${ }^{-1} \mathrm{~d}^{-1}$ (4.99 ng C predator ${ }^{-1} \mathrm{~d}^{-1}$ ). The prey concentration sustaining half of $I_{\max }$ was $2.2 \times 10^{3} \mathrm{cells} \mathrm{ml}^{-1}(287 \mathrm{ng}$ $\mathrm{C} \mathrm{ml}^{-1}$ ). The maximum clearance rate of $O$. marina on A. cf. poporum was $8.85 \mu$ l predator ${ }^{-1} \mathrm{~d}^{-1}$.

The ingestion rate of Strobilidium sp. on Azadinium cf. poporum increased rapidly with mean

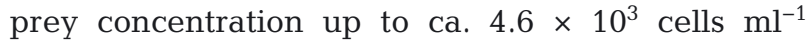
(590 $\mathrm{ng} \mathrm{C} \mathrm{ml}{ }^{-1}$ ). The ingestion rate continued to increase until the maximum prey concentration was reached at $5.8 \times 10^{4}$ cells ml$)^{-1}\left(7.5 \times 10^{3} \mathrm{ng} \mathrm{C} \mathrm{ml}^{-1}\right)$, but at a slower rate (Fig. 4B). When the data were fit-

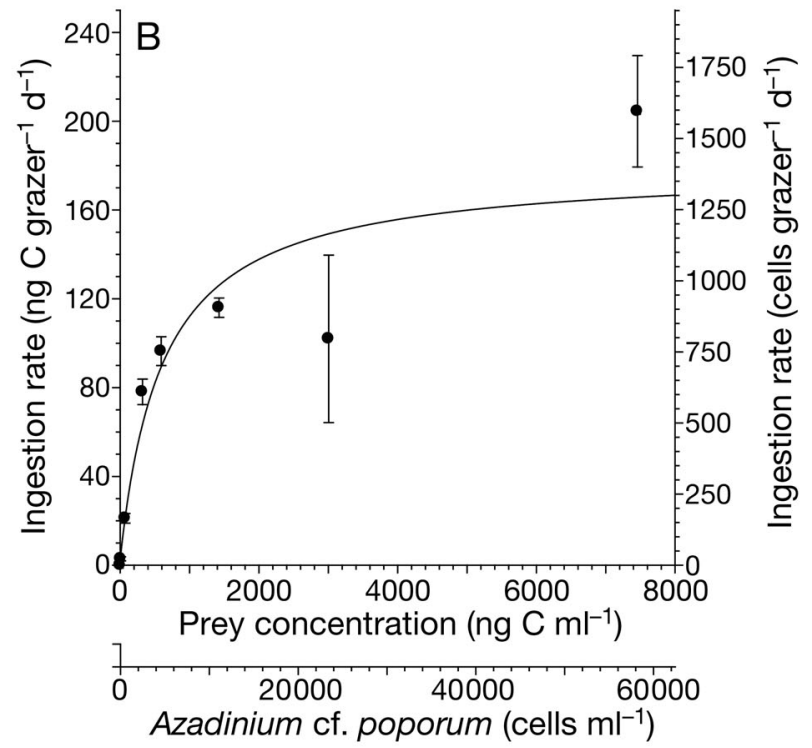

Fig. 4. Oxyrrhis marina, Strobilidium sp., and Acartia spp. Ingestion rate (IR) of (A) the heterotrophic dinoflagellate, (B) a ciliate, and $(C)$ copepods feeding on the dinoflagellate Azadinium cf. poporum as a function of mean prey concentration $(X)$. Symbols represent treatment means \pm 1 SE. A Michaelis-Menten equation (Eq. 3) was used to produce the curves for (A) and (B), while a simple linear regression equation (Eq. 4) was used to produce the curve for (C) for all treatments in the experiments. (A) IR $=4.99 X /(287+X), \mathrm{r}^{2}=$ 0.581 ; (B) IR $=179 X /(608+X), \mathrm{r}^{2}=0.777$; (C) IR $=2.63 X+$ $55.6, \mathrm{r}^{2}=0.707$

ted to Eq. (3), the $I_{\max }$ of Strobilidium sp. on A. cf. poporum was $1.4 \times 10^{3}$ cells predator ${ }^{-1} \mathrm{~d}^{-1}(179 \mathrm{ng} \mathrm{C}$ predator $\left.^{-1} \mathrm{~d}^{-1}\right)$. The prey concentration sustaining half of $I_{\max }$ was $4.8 \times 10^{3}$ cells ml ${ }^{-1}\left(608 \mathrm{ng} \mathrm{C} \mathrm{ml}^{-1}\right)$. The maximum clearance rate of Strobilidium sp. on A. cf. poporum was $346 \mu$ l predator ${ }^{-1} \mathrm{~d}^{-1}$.

The ingestion rate of Acartia spp. on Azadinium cf. poporum increased linearly up to ca. $5.5 \times 10^{4}$ cells $\mathrm{ml}^{-1}\left(7.0 \times 10^{3} \mathrm{ng} \mathrm{C} \mathrm{ml}^{-1}\right)$, the maximum prey concentration used (Fig. 4C). When the data were fitted to Eq. (4), the $I_{\max }$ of Acartia spp. at the maximum prey concentration tested was $1.4 \times 10^{5}$ cells predator ${ }^{-1} \mathrm{~d}^{-1}$ $\left(1.9 \times 10^{4} \mathrm{ng} \mathrm{C}\right.$ predator $\left.{ }^{-1} \mathrm{~d}^{-1}\right)$. The maximum clearance rate of Acartia spp. on A. cf. poporum was $8.4 \mathrm{ml}$ predator ${ }^{-1} \mathrm{~d}^{-1}$. 

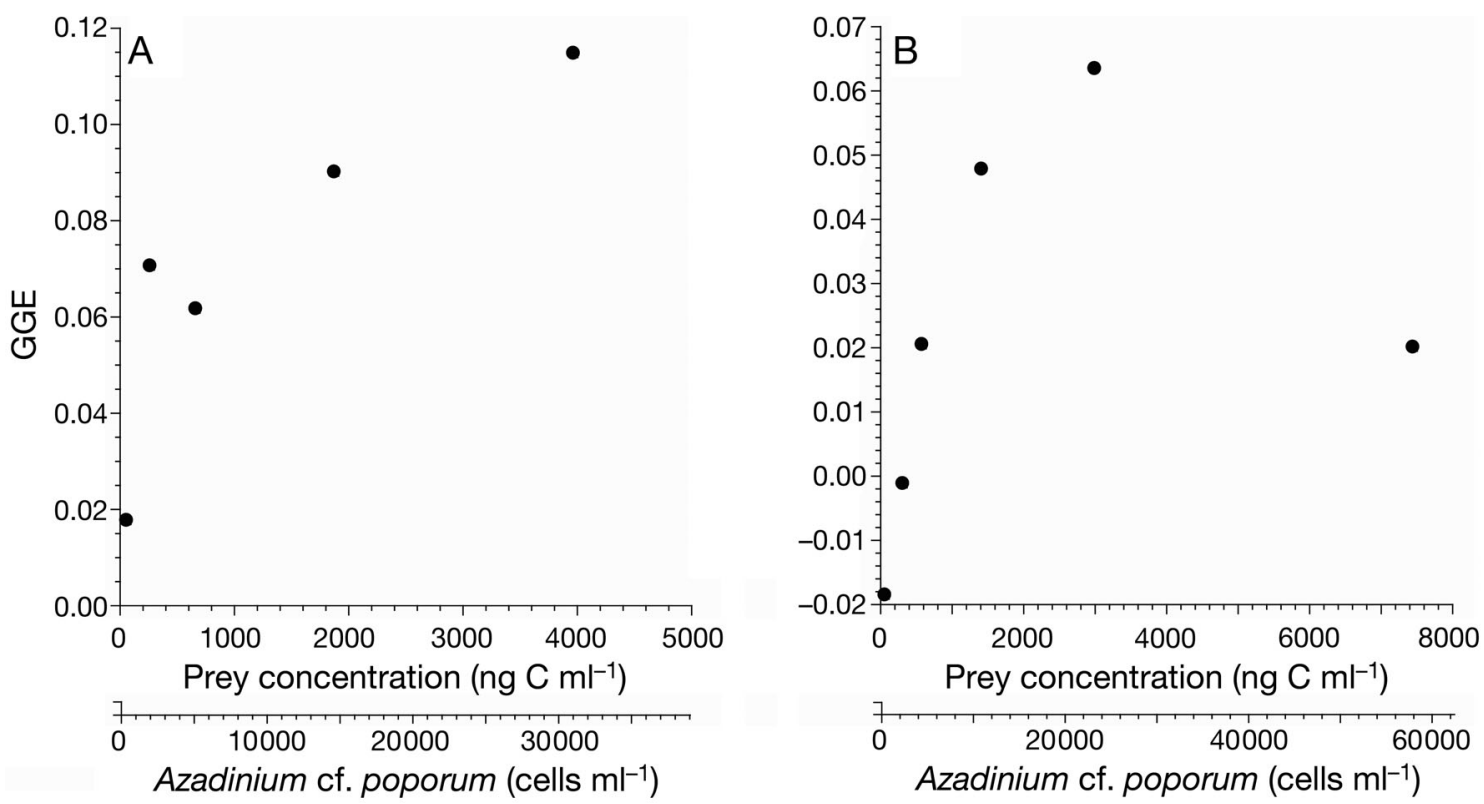

Fig. 5. Oxyrrhis marina and Strobilidium sp. Mean gross growth efficiencies (GGEs) of (A) the heterotrophic dinoflagellate and (B) a ciliate on Azadinium cf. poporum as a function of mean prey concentration. The GGEs at the first mean prey concentration are not illustrated since they were highly negative

\section{Gross growth efficiency}

The mean GGEs by predator-prey combination of Oxyrrhis marina on Azadinium cf. poporum generally increased with the mean prey concentrations. The GGEs were 6 to $11 \%$ at the prey concentrations for which ingestion rate was saturated (Fig. 5A). The mean GGEs by predator-prey combination of Strobilidium sp. on A. cf. poporum generally increased from the first mean prey concentration to $2.4 \times 10^{4}$ cells ml${ }^{-1}\left(3.01 \times 10^{3} \mathrm{ng} \mathrm{C} \mathrm{ml}^{-1}\right)$, the mean prey concentration preceding the last. However, Strobilidium sp. underwent a decrease of GGE at the last mean prey concentration $\left(5.8 \times 10^{4}\right.$ cells $\mathrm{ml}^{-1}, 7.5 \times 10^{3} \mathrm{ng} \mathrm{C} \mathrm{ml}{ }^{-1}$ ), likely caused by incomplete digestion, a phenomenon referred as 'superfluous feeding' (Straile 1997). The GGEs were 2 to $6 \%$ at prey concentrations $\geq 4.6 \times 10^{3}$ cells ml $^{-1}$ (590 ng C ml-1 ; Fig. 5B).

\section{Dynamics of Azadinium cf. poporum}

The 36 mo field survey conducted in Shiwha Bay showed that Azadinium cf. poporum cell concentrations were generally low (Fig. 6). The DNA of $A$. cf. poporum was detected each year of the survey. A. cf. poporum reached its highest concentration in Sep-

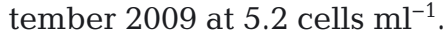

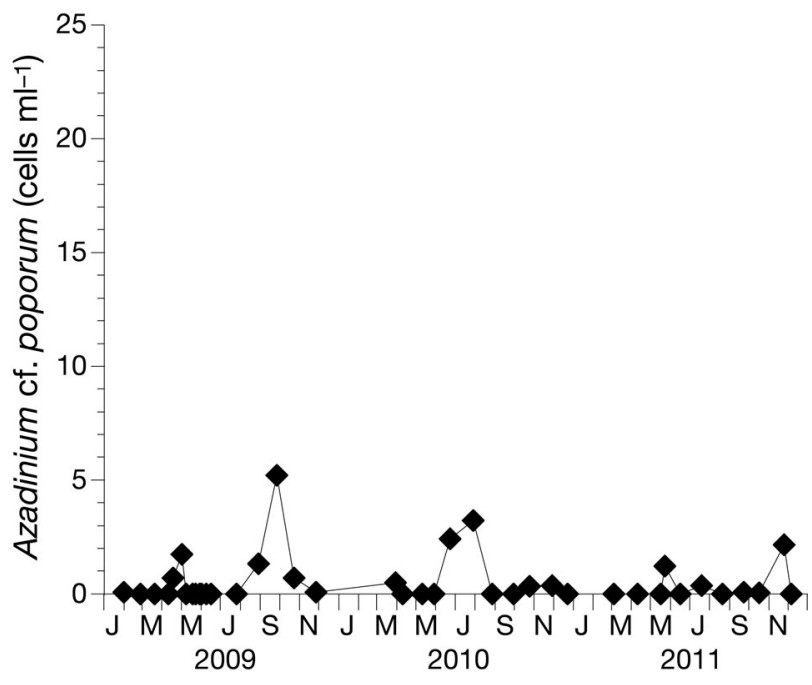

Fig. 6. Azadinium cf. poporum. Dynamics of abundances quantified by real-time PCR in Shiwha Bay, Korea, from 2009 to 2011. The highest values obtained at each sampling date are reported. The presence of ice prevented sampling in some months

\section{Grazing impact}

The grazing impact of Oxyrrhis marina was not possible to assess with the data provided by this study, since Azadinium cf. poporum and O. marina were not found to co-occur. However, Strobilidium 
sp.-sized naked ciliates (25 to $60 \mu \mathrm{m}$ in length) were observed to co-occur with $A$. cf. poporum in Shiwha Bay, Korea, between January 2009 and December 2011. Grazing coefficients were variable in a narrow range of concentrations for $A$. cf. poporum (0.2 to 3.2 cells $\mathrm{ml}^{-1}$ ) and Strobilidium sp.-sized naked ciliates ( 0.1 to 1.0 cells $\mathrm{ml}^{-1}$ ). Assuming that the ingestion rates of all Strobilidium sp.-sized naked ciliates on $A$. cf. poporum were the same as that of Strobilidium sp. obtained in this study, the grazing coefficients ranged between 0.052 and $0.446 d^{-1}(n=7$; Fig. 7$)$.

\section{Swimming speed}

The average $( \pm \mathrm{SE}, \mathrm{n}=30)$ and maximum swimming speeds of Azadinium cf. poporum, excluding the short and high-speed 'jumps' in various directions, at the given conditions were $416( \pm 13)$ and $550 \mu \mathrm{m} \mathrm{s}^{-1}$, respectively.

\section{DISCUSSION}

\section{Feeding}

This study is the first extensive report of feeding by HTDs, ciliates, and copepods on a species of the genus Azadinium. The engulfment feeders used in this study are raptorial feeders (Fenchel 1987, Sleigh 1989). These predators usually prefer prey approaching their size (Hansen et al. 1994). While the biggest engulfment feeder, Polykrikos kofoidii, did not feed on Azadinium cf. poporum, Gyrodinium spp. were of intermediate size and occasionally fed on A. cf. poporum. Oxyrrhis marina was the smallest engulfment feeder used in this study and revealed to be the most efficient on A. cf. poporum. Therefore, size is likely to be an important factor affecting the feeding of predators using engulfment on Azadinium spp. A particular case is $G$. fusus, which was previously suggested to be an important grazer on A. cf. spinosum (Akselman \& Negri 2012). Akselman \& Negri (2012) claimed that G. fusus is able to develop a hyaline cytoplasmic extension or feeding veil from its hypocone that reaches up to twice its length. This particularity was not observed with Gyrodinium spp. in our study and might explain the feeding efficiency of $G$. fusus on small prey such as A. cf. spinosum despite the difference in size. While size appears to be a relevant factor in feeding on $A$. cf. poporum for engulfment feeders, speed is unlikely to be a critical factor. For example, $P$. kofoidii

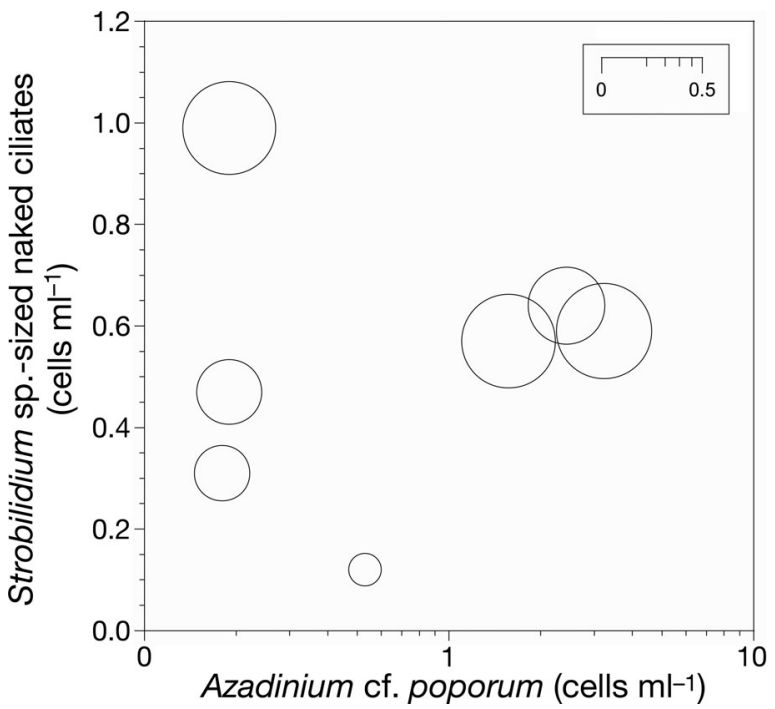

Fig. 7. Strobilidium sp.-sized naked ciliates (25 to $60 \mu \mathrm{m}$ in length). Calculated grazing coefficients of the ciliates $(n=7)$ in relation to the concentration of co-occurring Azadinium cf. poporum (see Eqs. $5 \& 6$ for calculation). Clearance rates were corrected with a $Q_{10}=2.8$ (Hansen et al. 1997) because in situ water temperatures and the experimental temperature used in the laboratory $\left(20^{\circ} \mathrm{C}\right)$ were sometimes different. Inset shows the scale of the circles that represent grazing coefficients $\left(g, d^{-1}\right)$

is known to feed on prey of similar speed (e.g. Gymnodinium catenatum mean speed: $450 \mu \mathrm{m} \mathrm{s}^{-1}$, maximum speed: $615 \mu \mathrm{m} \mathrm{s}^{-1}$; Yoo et al. 2010, this study).

Peduncle feeders can be highly specialized, such as Stoeckeria algicida which is only known to feed on Heterosigma akashiwo among algal prey (Jeong et al. 2005b, 2011a, this study). However, these predators are usually generalists and are able to feed on a wide range of dinoflagellates, but are restricted in size regarding thecal dinoflagellates. Peduncle feeders do not seem to have peduncles that are strong enough to efficiently penetrate the theca of dinoflagellates. Therefore, the theca might explain the absence of growth by both Pfiesteria piscicida and Gyrodiniellum shiwhaense despite the occurrence of feeding. Peduncle feeders are therefore unlikely to be effective predators on Azadinium spp.

The pallium feeder Oblea rotunda was not able to feed on Azadinium cf. poporum. O. rotunda responds to chemosensory, but not to mechanosensory, stimulation (Strom \& Buskey 1993). Therefore, the lack of chemosensory stimulation from $A$. cf. poporum might explain the lack of feeding by $O$. rotunda. P. crassipes, for which AZA-1, AZA-2, and AZA-3 have been detected (James et al. 2003), is likely to feed on Azadinium spp. or closely related species. Therefore, 

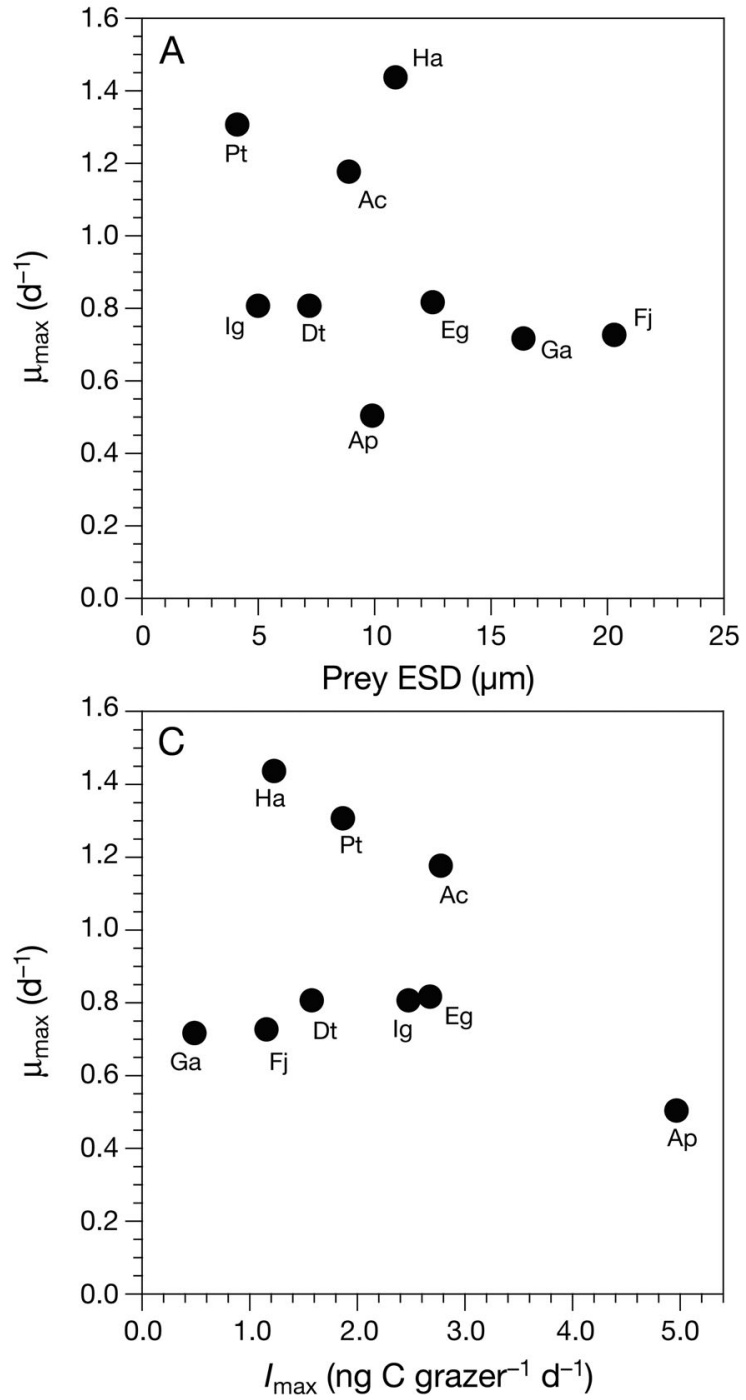

it is worthwhile to study feeding by pallium feeders on Azadinium spp. further in order to assess the potential of such predators.

The filter feeders Strobilidium sp. and Acartia spp. were both able to feed on Azadinium cf. poporum. However, not all filter feeders are likely to feed on Azadinium spp. The ciliate Laboea strobila as well as 3 unidentified oligotrich ciliate species were previously observed to co-occur with $A$. cf. spinosum. Among them, only 1 oligotrich ciliate was suggested to feed (Akselman \& Negri 2012). The facility of filter feeders to capture prey of smaller size (Hansen et al. 1994) might partly explain their success. However, more factors are apparently implicated in their capacity to feed on Azadinium spp.

Based on the results of the present study, the dynamics of HTDs that engulf their prey and are not disproportionately larger than Azadinium spp., as

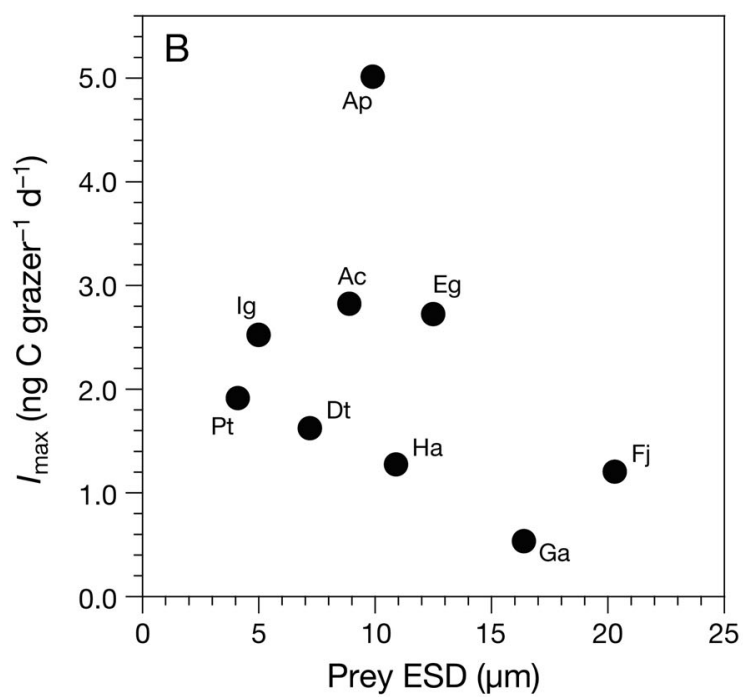

Fig. 8. Oxyrrhis marina. (A) Maximum growth $\left(\mu_{\max } \mathrm{d}^{-1}\right)$ and (B) ingestion rates $\left(I_{\max }, \mathrm{ng} \mathrm{C}\right.$ predator $\left.{ }^{-1} \mathrm{~d}^{-1}\right)$ of the heterotrophic dinoflagellate feeding on photosynthetic or mixotrophic algal prey as a function of prey size (equivalent spherical diameter, ESD, $\mu \mathrm{m})$, and (C) $\mu_{\max }$ as a function of $I_{\max }$. Ac: Amphidinium carterae; Ap: Azadinium cf. poporum; Dt: Dunaliella tertiolecta; Eg: Eutreptiella gymnastica; Fj: Fibrocapsa japonica; Ga: Gymnodinium aureolum; Ha: Heterosigma akashiwo; Ig: Isochrysis galbana; Pt: Phaeodactylum tricornutum. Control laboratory experiments were made at $20^{\circ} \mathrm{C}$. ESDs were estimated based on prey volume or carbon content converted to prey volume according to Menden-Deuer \& Lessard (2000) if not provided. Ingestion rates from Goldman et al. (1989) were converted from cell to carbon according to Menden-Deuer \& Lessard (2000). The $\mu_{\max }$ and $I_{\max }$ on algal prey were obtained from Goldman et al. (1989), Jeong et al. (2001, 2003b), Tillmann \& Reckermann (2002), and Yoo et al. (2010)

well as ciliates which use filtration, are more likely to be affected by the occurrence of Azadinium spp. than HTDs that feed using their peduncle.

\section{Growth and ingestion rates}

The $\mu_{\max }$ of the predators of Azadinium cf. poporum were the lowest among known photosynthetic or mixotrophic prey enabling growth (Figs. 8A \& 9A; Goldman et al. 1989, Montagnes 1996, Jeong et al. 2001, 2003b, Tillmann \& Reckermann 2002, Chen et al. 2010, Yoo et al. 2010), while the $I_{\max }$ values were the highest (Figs. 8B, 9B, \& 10; Houde \& Roman 1987, Goldman et al. 1989, Jeong et al. 2001, 2003b, Besiktepe \& Dam 2002, Tillmann \& Reckermann 2002, Broglio et al. 2003, Cohen et al. 2007, Chen et al. 2010, Yoo et al. 2010). The low ratios of maximum 

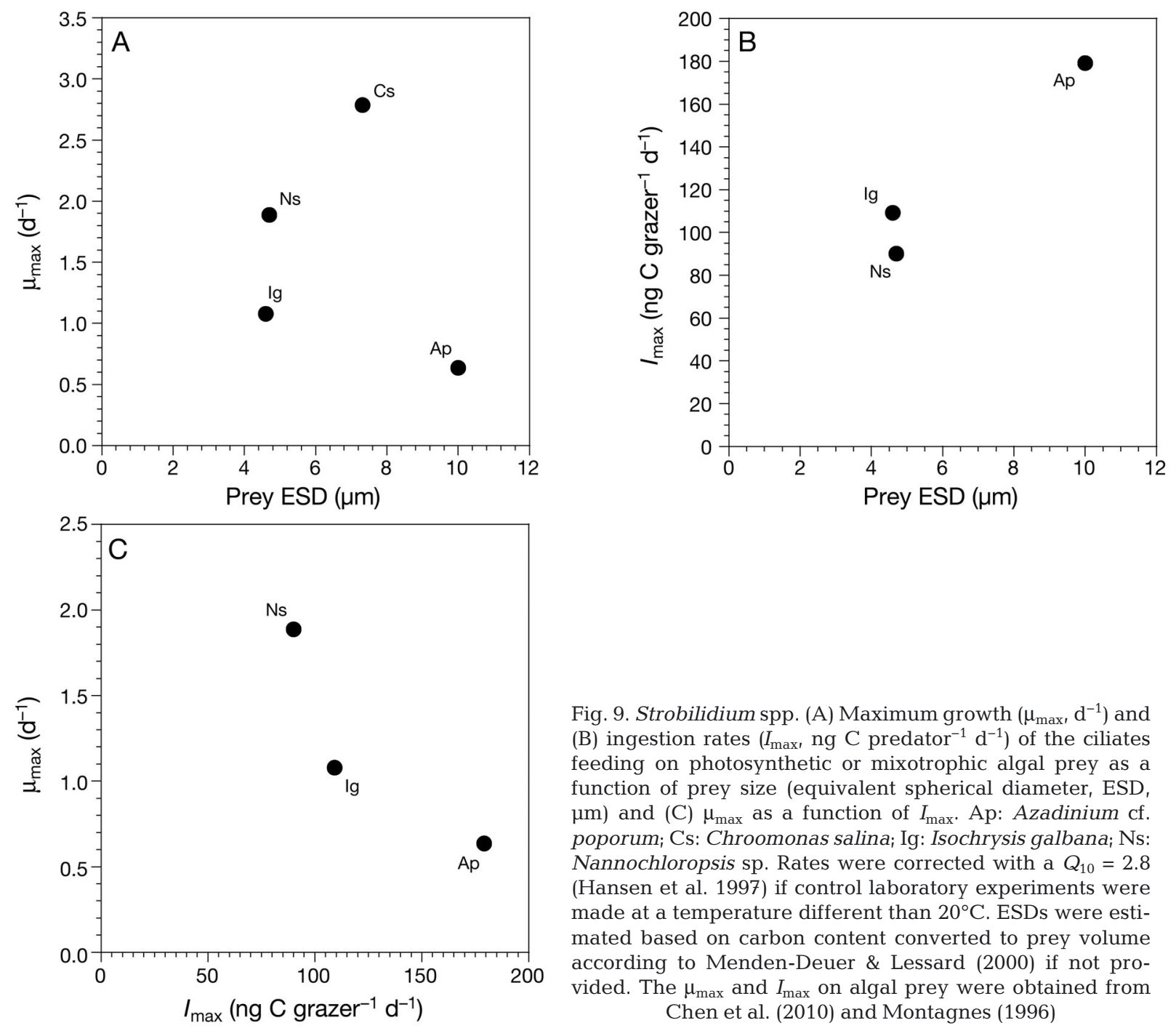

Fig. 9. Strobilidium spp. (A) Maximum growth $\left(\mu_{\max }, \mathrm{d}^{-1}\right)$ and (B) ingestion rates $\left(I_{\max }\right.$, ng C predator $\left.{ }^{-1} \mathrm{~d}^{-1}\right)$ of the ciliates feeding on photosynthetic or mixotrophic algal prey as a function of prey size (equivalent spherical diameter, ESD, $\mu \mathrm{m})$ and $(\mathrm{C}) \mu_{\max }$ as a function of $I_{\max }$. Ap: Azadinium cf. poporum; Cs: Chroomonas salina; Ig: Isochrysis galbana; Ns: Nannochloropsis sp. Rates were corrected with a $Q_{10}=2.8$ (Hansen et al. 1997) if control laboratory experiments were made at a temperature different than $20^{\circ} \mathrm{C}$. ESDs were estimated based on carbon content converted to prey volume according to Menden-Deuer \& Lessard (2000) if not provided. The $\mu_{\max }$ and $I_{\max }$ on algal prey were obtained from Chen et al. (2010) and Montagnes (1996)

Fig. 10. Acartia spp. Maximum ingestion rate $\left(I_{\max }, \mu g \mathrm{C}\right.$ predator ${ }^{-1} \mathrm{~d}^{-1}$ ) of the copepods on photosynthetic or mixotrophic algal prey as a function of prey size (equivalent spherical diameter, ESD, $\mu \mathrm{m})$. Ac: Amphidinium carterae*; Ap: Azadinium cf. poporum*; Gs: Gymnodinium sanguineum*; $\mathrm{Kb}$ : Karenia brevis ${ }^{*}{ }_{;} \mathrm{Pm}_{1}{ }^{*}$ and $\mathrm{Pm}_{2}$ : Prorocentrum minimum. Rates were corrected with a $Q_{10}=2.8$ (Hansen et al. 1997) if control laboratory experiments were unambiguously made at a temperature different than $20^{\circ} \mathrm{C}$. ESDs were estimated based on carbon content converted to prey volume according to Menden-Deuer \& Lessard (2000) if not provided. The $I_{\max }$ on algal prey were obtained from Houde \& Roman (1987), Besiktepe \& Dam (2002), Broglio et al. (2003), and Cohen et al. (2007). ${ }^{*}$ Maximum value obtained

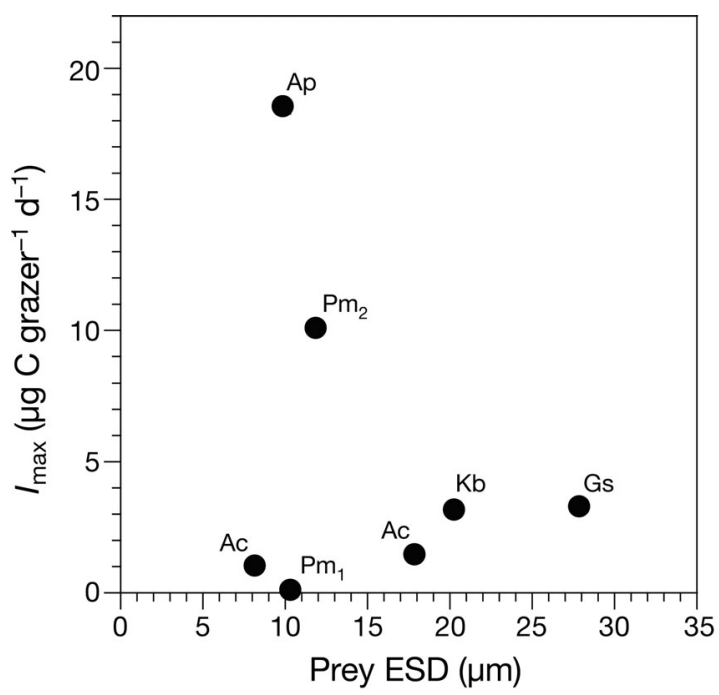


growth rate to maximum ingestion rate, or RMGI, and GGEs obtained by predators in this study suggest that $A$. cf. poporum is a low-quality prey. The energy necessary to capture, handle, and digest this prey is higher than for other prey species, or the conversion of ingested $A$. cf. poporum carbon to predator body carbon is low. This can lead the predators to compensate for the low quality of $A$. cf. poporum by feeding more and explains the high ingestion rates obtained in the laboratory experiments. A. cf. poporum is the only known photosynthetic or mixotrophic thecate prey species for Oxyrrhis marina and Strobilidium sp. for which we have quantitative data on growth and ingestion rates. The theca of $A$. cf. poporum might be partly responsible for its reduced quality as prey. It is also possible that the azaspiracid produced by A. cf. poporum (Krock et al. 2012) lowers its quality as prey.

\section{Dynamics of Azadinium cf. poporum}

The survey of Azadinium cf. poporum by real-time PCR revealed that the species is always in low concentration in Shiwha Bay. In this respect, it appears that $A$. cf. poporum acts similarly to A. caudatum (Nézan et al. 2012). The reasons explaining these observations are unknown. Predation on A. cf. poporum as well as the physiology of the species can result in such dynamics.

\section{Grazing impact}

The grazing coefficients obtained by using field data on abundance of Strobilidium sp.-sized naked ciliates (25 to $60 \mu \mathrm{m}$ in length) co-occurring with Azadinium cf. poporum as well as laboratory data on ingestion rates suggest that up to $36 \%$ of the $A$. cf. poporum population could be removed by Strobilidium sp.-sized naked ciliates in $1 \mathrm{~d}$. However, it is unclear whether such an impact is reflected in the field with a more complex microbial food web. The high ingestion rates obtained in laboratory experiments, as mentioned above, might be influenced by compensatory feeding. Furthermore, oligotrich ciliates are known to select food based on size (Kivi \& Setälä 1995). However, ciliates have also shown selectivity at the species level (Stoecker et al. 1981, Verity 1988). Therefore, it is questionable to what extent the grazing impacts obtained in this study reflect what is actually happening in the field.

\section{Ecological implications}

Many predators are able to feed on Azadinium cf. poporum. However, only 2 predators used in this study responded with acute growth on $A$. cf. poporum. Furthermore, $A$. cf. poporum appears to be a low-quality prey for the planktonic predators tested here based on the RMGI and GGEs obtained. If this can be generalized at the genus level, it suggests that only a few predators are likely to feed efficiently on Azadinium spp. The abundances of $A$. cf. poporum in the field are revealed to be below or slightly above the threshold prey concentration of the predators. Therefore, A. cf. poporum is unlikely to affect the dynamics of these predators in the field. This is reflected by the absence or low co-occurrence of the protistan predators with $A$. cf. poporum over the $3 \mathrm{yr}$ of monitoring. Factors other than predation are likely to be implicated in the determination of the abundance of $A$. cf. poporum in the field. Further research is required to determine these factors.

Acknowledgements. We are grateful to the anonymous reviewers for helpful comments. We thank J. W. Park and K. A. Seong for technical support. This paper was funded by a PhD scholarship from the Fonds de Recherche du QuébecNature et Technologies awarded to É.P. and grants from the National Research Foundation (2012-R1A2A201-010987) and Ecological Disturbance Research Program of the Korea Institute of Marine Science \& Technology Promotion/Ministry of Land, Transportation and Marine Affairs (KMLTM) awarded to H.J.J.

\section{LITERATURE CITED}

Akselman R, Negri RM (2012) Blooms of Azadinium cf. spinosum Elbrächter et Tillmann (Dinophyceae) in northern shelf waters of Argentina, Southwestern Atlantic. Harmful Algae 19:30-38

Alfonso A, Vieytes MR, Ofuji K, Satake M, Nicolaou KC, Frederick MO, Botana LM (2006) Azaspiracids modulate intracellular $\mathrm{pH}$ levels in human lymphocytes. Biochem Biophys Res Commun 346:1091-1099

Besiktepe S, Dam HG (2002) Coupling of ingestion and defecation as a function of diet in the calanoid copepod Acartia tonsa. Mar Ecol Prog Ser 229:151-164

Broglio E, Jónasdóttir SH, Calbet A, Jakobsen HH, Saiz E (2003) Effect of heterotrophic versus autotrophic food on feeding and reproduction of the calanoid copepod Acartia tonsa: relationship with prey fatty acid composition. Aquat Microb Ecol 31:267-278

Brownlee DC, Jacobs F (1987) Mesozooplankton and microzooplankton in the Chesapeake Bay. In: Majumdar SK, Hall LW Jr, Austin HM (eds) Contaminant problems and management of living Chesapeake Bay resources. The Pennsylvania Academy of Science, Easton, PA, p 217-269

Chen B, Liu H, Lau MTS (2010) Grazing and growth responses of a marine oligotrichous ciliate fed with two 
nanoplankton: Does food quality matter for micrograzers? Aquat Ecol 44:113-119

Cohen JH, Tester PA, Forward RB Jr (2007) Sublethal effects of the toxic dinoflagellate Karenia brevis on marine copepod behavior. J Plankton Res 29:301-315

Colman JR, Twiner MJ, Hess P, McMahon T and others (2005) Teratogenic effects of azaspiracid-1 identified by microinjection of Japanese medaka (Oryzias latipes) embryos. Toxicon 45:881-890

Fenchel T (1987) Ecology of protozoa - the biology of freeliving phagotrophic protists. Springer-Verlag, New York, NY

$>$ Frost BW (1972) Effects of size and concentration of food particles on the feeding behavior of the marine planktonic copepod Calanus pacificus. Limnol Oceanogr 17: 805-815

> Goldman JC, Dennett MR, Gordin H (1989) Dynamics of herbivorous grazing by the heterotrophic dinoflagellate Oxyrrhis marina. J Plankton Res 11:391-407

> Guillard RRL, Ryther JH (1962) Studies of marine planktonic diatoms. I. Cyclotella nana Hustedt, and Detonula confervacea (Cleve) Gran. Can J Microbiol 8:229-239

- Hansen B, Bjørnsen PK, Hansen PJ (1994) The size ratio between planktonic predators and their prey. Limnol Oceanogr 39:395-403

> Hansen PJ, Bjørnsen PK, Hansen BW (1997) Zooplankton grazing and growth: scaling within the $2-2,000-\mu \mathrm{m}$ body size range. Limnol Oceanogr 42:687-704

Heinbokel JF (1978) Studies on the functional role of tintinnids in the Southern California Bight. I. Grazing and growth rates in laboratory cultures. Mar Biol 47: 177-189

$>$ Houde SEL, Roman MR (1987) Effects of food quality on the functional ingestion response of the copepod Acartia tonsa. Mar Ecol Prog Ser 40:69-77

Ito E, Satake M, Ofuji K, Higashi M, Harigaya K, McMahon $\mathrm{T}$, Yasumoto T (2002) Chronic effects in mice caused by oral administration of sublethal doses of azaspiracid, a new marine toxin isolated from mussels. Toxicon 40: 193-203

> James KJ, Moroney C, Roden C, Satake M, Yasumoto T, Lehane M, Furey A (2003) Ubiquitous 'benign' alga emerges as the cause of shellfish contamination responsible for the human toxic syndrome, azaspiracid poisoning. Toxicon 41:145-151

> Jeong HJ (1999) The ecological roles of heterotrophic dinoflagellates in marine planktonic community. J Eukaryot Microbiol 46:390-396

Jeong HJ, Kang H, Shim JH, Park JK, Kim JS, Song JY, Choi HJ (2001) Interactions among the toxic dinoflagellate Amphidinium carterae, the heterotrophic dinoflagellate Oxyrrhis marina, and the calanoid copepods Acartia spp. Mar Ecol Prog Ser 218:77-86

Jeong HJ, Park KH, Kim JS, Kang H and others (2003a) Reduction in the toxicity of the dinoflagellate Gymnodinium catenatum when fed on by the heterotrophic dinoflagellate Polykrikos kofoidii. Aquat Microb Ecol 31: 307-312

Jeong HJ, Kim JS, Yoo YD, Kim ST and others (2003b) Feeding by the heterotrophic dinoflagellate Oxyrrhis marina on the red-tide raphidophyte Heterosigma akashiwo: a potential biological method to control red tides using mass-cultured grazers. J Eukaryot Microbiol 50:274-282

Jeong HJ, Kim JS, Park JY, Kim JH and others (2005a) Stoeckeria algicida n. gen., n. sp. (Dinophyceae) from the coastal waters off southern Korea: morphology and small subunit ribosomal DNA gene sequence. J Eukaryot Microbiol 52:382-390

Jeong HJ, Kim JS, Kim JH, Kim ST and others (2005b) Feeding and grazing impact of the newly described heterotrophic dinoflagellate Stoeckeria algicida on the harmful alga Heterosigma akashiwo. Mar Ecol Prog Ser 295: 69-78

> Jeong HJ, Ha JH, Park JY, Kim JH and others (2006) Distribution of the heterotrophic dinoflagellate Pfiesteria piscicida in Korean waters and its consumption of mixotrophic dinoflagellates, raphidophytes and fish blood cells. Aquat Microb Ecol 44:263-278

Jeong HJ, Yoo YD, Kim JS, Seong KA, Kang NS, Kim TH (2010) Growth, feeding and ecological roles of the mixotrophic and heterotrophic dinoflagellates in marine planktonic food webs. Ocean Sci J 45:65-91

Jeong HJ, Lee KH, Yoo YD, Kang NS, Lee K (2011a) Feeding by the newly described, nematocyst-bearing heterotrophic dinoflagellate Gyrodiniellum shiwhaense. J Eukaryot Microbiol 58:511-524

> Jeong HJ, Kim TH, Yoo YD, Yoon EY and others (2011b) Grazing impact of heterotrophic dinoflagellates and ciliates on common red-tide euglenophyte Eutreptiella gymnastica in Masan Bay, Korea. Harmful Algae 10: 576-588

> Kang NS, Jeong HJ, Moestrup Ø, Park TG (2011) Gyrodiniellum shiwhaense n. gen., n. sp., a new planktonic heterotrophic dinoflagellate from the coastal waters of western Korea: morphology and ribosomal DNA gene sequence. J Eukaryot Microbiol 58:284-309

Kibbe WA (2007) OligoCalc: an online oligonucleotide properties calculator. Nucleic Acids Res 35:W43-W46

Kim JS, Jeong HJ (2004) Feeding by the heterotrophic dinoflagellates Gyrodinium dominans and G. spirale on the red-tide dinoflagellate Prorocentrum minimum. Mar Ecol Prog Ser 280:85-94

Kivi K, Setälä O (1995) Simultaneous measurement of food particle selection and clearance rates of planktonic oligotrich ciliates (Ciliophora: Oligotrichina). Mar Ecol Prog Ser 119:125-137

Krock B, Tillmann U, John U, Cembella AD (2009) Characterization of azaspiracids in plankton size-fractions and isolation of an azaspiracid-producing dinoflagellate from the North Sea. Harmful Algae 8:254-263

Krock B, Tillmann U, Voß D, Koch BP and others (2012) New azaspiracids in Amphidomataceae (Dinophyceae). Toxicon 60:830-839

Kulagina NV, Twiner MJ, Hess P, McMahon T and others (2006) Azaspiracid-1 inhibits bioelectrical activity of spinal cord neuronal networks. Toxicon 47:766-773

Larkin MA, Blackshields G, Brown NP, Chenna R and others (2007) Clustal W and Clustal X version 2.0. Bioinformatics 23:2947-2948

Lessard EJ (1991) The trophic role of heterotrophic dinoflagellates in diverse marine environments. Mar Microb Food Webs 5:49-58

> Menden-Deuer S, Lessard EJ (2000) Carbon to volume relationships for dinoflagellates, diatoms, and other protist plankton. Limnol Oceanogr 45:569-579

Michaelis L, Menten ML (1913) Die Kinetik der Invertinwirkung. Biochem Z 49:333-369

Montagnes DJS (1996) Growth responses of planktonic ciliates in the genera Strobilidium and Strombidium. Mar Ecol Prog Ser 130:241-254 
Nézan E, Tillmann U, Bilien G, Boulben S and others (2012) Taxonomic revision of the dinoflagellate Amphidoma caudata: transfer to the genus Azadinium (Dinophyceae) and proposal of two varieties, based on morphological and molecular phylogenetic analyses. J Phycol 48: 925-939

Painting SJ, Lucas MI, Peterson WT, Brown PC, Hutchings L, Mitchell-Innes BA (1993) Dynamics of bacterioplankton, phytoplankton and mesozooplankton communities during the development of an upwelling plume in the southern Benguela. Mar Ecol Prog Ser 100:35-53

Potvin É, Jeong HJ, Kang NS, Tillmann U, Krock B (2012) First report of the photosynthetic dinoflagellate genus Azadinium in the Pacific Ocean: morphology and molecular characterization of $A$. cf. poporum. J Eukaryot Microbiol 59:145-156

Román Y, Alfonso A, Louzao MC, de la Rosa LA and others (2002) Azaspiracid-1, a potent, nonapoptotic new phycotoxin with several cell targets. Cell Signal 14:703-716

Rozen S, Skaletsky HJ (2000) Primer3 on the WWW for general users and for biologist programmers. In: Krawetz S, Misener S (eds) Bioinformatics methods and protocols: methods in molecular biology. Humana Press, Totowa, NJ, p 365-386

Sherr EB, Sherr BF (2007) Heterotrophic dinoflagellates: a significant component of microzooplankton biomass and major grazers of diatoms in the sea. Mar Ecol Prog Ser 352:187-197

Sleigh MA (1989) Protozoa and other protists. Edward Arnold, New York, NY

Soh HY, Suh HL (2000) A new species of Acartia (Copepoda, Calanoida) from the Yellow Sea. J Plankton Res 22: 321-337

Stoecker D, Guillard RRL, Kavee RM (1981) Selective predation by Favella ehrenbergii (Tintinnia) on and among dinoflagellates. Biol Bull (Woods Hole) 160:136-145

Straile D (1997) Gross growth efficiencies of protozoan and metazoan zooplankton and their dependence on food concentration, predator-prey weight ratio, and taxonomic group. Limnol Oceanogr 42:1375-1385

Strom SL, Buskey EJ (1993) Feeding, growth, and behavior of the thecate heterotrophic dinoflagellate Oblea rotunda. Limnol Oceanogr 38:965-977

Strom SL, Postel JR, Booth BC (1993) Abundance, variability, and potential grazing impact of planktonic ciliates in the open subarctic Pacific Ocean. Prog Oceanogr 32:185-203

Tillmann U, Reckermann M (2002) Dinoflagellate grazing on the raphidophyte Fibrocapsa japonica. Aquat Microb Ecol 26:247-257

Editorial responsibility: Patricia Glibert, Cambridge, Maryland, USA
Tillmann U, Elbrächter M, Krock B, John U, Cembella A (2009) Azadinium spinosum gen. et sp. nov. (Dinophyceae) identified as a primary producer of azaspiracid toxins. Eur J Phycol 44:63-79

> Tillmann U, Elbrächter M, John U, Krock B, Cembella A (2010) Azadinium obesum (Dinophyceae), a new nontoxic species in the genus that can produce azaspiracid toxins. Phycologia 49:169-182

> Tillmann U, Elbrächter M, John U, Krock B (2011) A new non-toxic species in the dinoflagellate genus Azadinium: A. poporum sp. nov. Eur J Phycol 46:74-87

Tillmann U, Salas R, Gottschling M, Krock B, O'Driscoll D, Elbrächter M (2012) Amphidoma languida sp. nov. (Dinophyceae) reveals a close relationship between Amphidoma and Azadinium. Protist 163:701-719

Turner JT, Doucette GJ, Keafer BA, Anderson DM (2005) Trophic accumulation of PSP toxins in zooplankton during Alexandrium fundyense blooms in Casco Bay, Gulf of Maine, April-June 1998. II. Zooplankton abundance and size-fractionated community composition. Deep-Sea Res II 52:2784-2800

- Twiner MJ, Hess P, Bottein Dechraoui MY, McMahon T and others (2005) Cytotoxic and cytoskeletal effects ofazaspiracid-1 on mammalian cell lines. Toxicon 45: 891-900

Twiner MJ, Rehmann N, Hess P, Doucette GJ (2008) Azaspiracid shellfish poisoning: a review on the chemistry, ecology, and toxicology with an emphasis on human health impacts. Mar Drugs 6:39-72

- Vale C, Nicolaou KC, Frederick MO, Gómez-Limia B, Alfonso A, Vieytes MR, Botana LM (2007) Effects of azaspiracid-1, a potent cytotoxic agent, on primary neuronal cultures. A structure-activity relationship study. J Med Chem 50:356-363

Verity PG (1988) Chemosensory behavior in marine planktonic ciliates. Bull Mar Sci 43:772-782

Watras CJ, Garcon VC, Olson RJ, Chisholm SW, Anderson DM (1985) The effect of zooplankton grazing on estuarine blooms of the toxic dinoflagellate Gonyaulax tamarensis. J Plankton Res 7:891-908

Yoo YD, Jeong HJ, Kang NS, Kim JS, Kim TH, Yoon EY (2010) Ecology of Gymnodinium aureolum. II. Predation by common heterotrophic dinoflagellates and a ciliate. Aquat Microb Ecol 59:257-272

> Yoon EY, Kang NS, Jeong HJ (2012) Gyrodinium moestrupii n. sp., a new planktonic heterotrophic dinoflagellate from the coastal waters of western Korea: morphology and ribosomal DNA gene sequence. J Eukaryot Microbiol 59: 571-586

Submitted: April 4, 2012; Accepted: October 12, 2012

Proofs received from author(s): January 15, 2013 